\section{Embryo Culture of Fraxinus ornus and Sorbus domestica Removes Seed Dormancy}

\author{
Isabel Arrillaga, Toni Marzo, and Juan Segura \\ Departamento de Biología Vegetal, Facultad de Farmacia. Avda Blasco \\ Ibañez, 13, 46010-Valencia, Spain
}

Additional index words. flowering ash, service tree, seed germination, tissue culture

We herein describe a rapid method to break seed dormancy of flowering ash (Fraxinus ornus L.) and service tree (Sorbus domestica L.) by using embryo culture techniques, because seeds of these trees commonly exhibit some degree of dormancy (Hartmann et al., 1990).

Mature fruits of service tree and flowering ash were harvested during Fall 1989 from several widely spaced trees growing in their natural habitat: Las Cuevas de Vinromá (Castellón) and La Fuente del Enebro (Valencia), respectively. Seeds of service tree were isolated by fruit maceration in water and floatation (viable seeds sink and nonviable seeds and pulp float). Viable seeds were then blotted and allowed to dry for 3 to 4 days at room temperature (18 to 20C). Seeds of flowering ash were removed from hand-detached fruits. Following seed extraction, seeds (7\% to $9 \%$ moisture content) were stored at $4 \mathrm{C}$ in dehumidifiers with silica gel.

The germination medium consisted of $3 \%$ sucrose and $0.7 \%$ Difco-Bacto agar in distilled water ( $\mathrm{pH}$ of 5.8). The medium was autoclaved at $120 \mathrm{C}$ for $20 \mathrm{~min}$ and then pensed $(25 \mathrm{ml} /$ dish $)$ in glass petri dishes $(100$ $\times 15 \mathrm{~mm}$ ). Before culture, seeds were sterilized by immersion in $70 \%$ ethanol for 30 sec followed by $30 \mathrm{~min}$ in $3 \% \mathrm{NaOCl}$ with $0.1 \%$ Tween-20 and rinsed several times with sterile distilled water. One lot of intact seeds from each species (control) was placed onto the germination medium (10 seeds per dish). The remaining seeds were kept either in sterile-distilled water, a filter-sterilized solution of $11.5 \mu \mathrm{M}$ gibberellic acid $\left(\mathrm{GA}_{3}\right)$, or a sterile solution of $100 \mathrm{mg} \cdot$ liter $^{-1}$ each citric and ascorbic acids for 24,48 , or $72 \mathrm{~h}$ at $26 \pm$ $2 \mathrm{C}$. Once imbibed, the seeds were again sterilized $(1 \% \mathrm{NaOCl}$ with $0.1 \%$ Tween-20 for $15 \mathrm{~min}$ ) and rinsed in sterile-distilled

Received for publication 15 July 1991. Accepted for publication 17 Oct. 1991. This research was supported by the Conselleria de Cultura, Educación y Ciencia, Generalitat Valenciana, Spain. Grant to I.A. The cost of publishing this paper was defrayed in part by the payment of page charges. Under postal regulations, this paper therefore must be hereby marked advertisement solely to indicate this fact. each consisting of 20 seeds or embryos. water. Half the seeds were placed on the germination medium, and embryos of the remaining seeds were aseptically excised and cultured as above. The dishes, sealed with Parafilm, were maintained in a growth chamber at $26 \pm 2 \mathrm{C}$ with a 16 -h photoperiod of $20 \mathrm{~W} \cdot \mathrm{m}^{-2}$ provided by cool-white fluorescent lamps (Sylvania GTE Gro-lux, F36W/GRO, Erlangen, Germany). One hundred seeds or embryos from each species, distributed in five experimental units (each consisting of 20 seeds or embryos), were cultured for each treatment. After $\approx 2$ weeks, germinating seeds or embryos were transferred to glass tubes $(25 \times 150 \mathrm{~mm})$ containing $25 \mathrm{ml}$ of a Murashige and Skoog (1962) (MS) medium with 3\% sucrose and $0.7 \%$ agar ( $\mathrm{pH} 5.8)$. Data on germination (percentage of plants recovered from cultured seeds and embryos) were recorded after 30 days. This experiment was conducted three times using a completely randomized design. Transformed data (angular transformation of the germination percentages) were subjected to analysis of variance.

Nontreated seeds (control) of service tree failed to germinate and only $7 \%$ of nontreated seeds of flowering ash germinated. Imbibition did not markedly improve ger- mination when intact seeds were used. In contrast, excision of the embryos stimulated germination in both species. For excised embryos, the first visible signs of germination were the divergence and greening of the cotyledons followed by radicle elongation. Germinating seeds and embryos developed into plantlets when transferred to MS medium (Tables 1 and 2). Germination of seeds of flowering ash or service tree was improved most by isolation and in-vitro culture of embryos. Prolongated imbibition of seeds of flowering ash in water or citric and ascorbic acid solution reduced the number of plants recovered from seeds or isolated embryos (Table 2).

Inhibition of germination by seed dormancy has been overcome by in-vitro culture of embryos in many species (Collins and Grosser, 1984; Ho, 1987; Ramming, 1990). Data herein clearly indicate that this technique is highly effective in service tree and flowering ash and also provides a source of explants for in-vitro culture of these trees in a relatively short period.

\section{Literature cited}

Collins, G.B. and J.W.C. Grosser. 1984. Culture of embryos, p. 241-257. In: I.K. Vasil (ed.). Cell culture and somatic cell genetics of plants. vol. 1. Laboratory procedures and their applications. Academic, Orlando, Fla.

Hartmann, H.T., D.E. Kester, and F.T. Davies, Jr. 1990. Plant propagation, principles and practices. 5th ed. Prentice-Hall, London.

Ho, R.H. 1987. Embryo culture, p. 137-167. In: J.M Bonga and J. Durzan (eds.). Cell and tissue culture in forestry. vol. 2. Martinus Nijhoff, Dordrech, The Netherlands.

Murashige, T. and F. Skoog. 1962. A revised medium for rapid growth and bioassays with tobacco tissue cultures. Physiol. Plant. 15:473497.

Ramming, D.W. 1990. The use of embryo culture in fruit breeding. HortScience 25:393-398.

Table 1. Effect of various seed imbibition treatments on the recovery of plants (germination) of service tree and flowering ash from in vitro cultured seeds and embryos. Values are means of five replications,

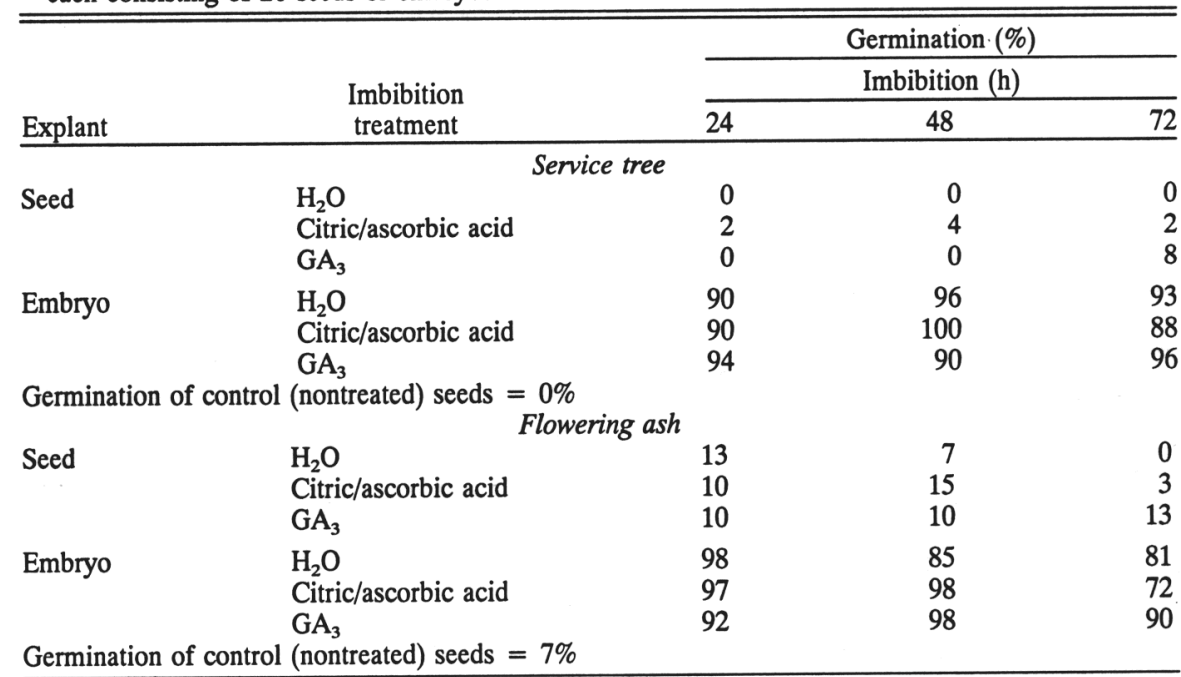

